\title{
Comparative Study of Indirect Fluorescent Antibody, ELISA, and Immunochromatography Tests for Serological Diagnosis of Bovine Babesiosis Caused by Babesia bovis
}

\author{
José Juan Lira-Amaya ${ }^{1}$, Grecia Martínez-García ${ }^{1}{ }^{10}$, R. Montserrat Santamaria-Espinosa ${ }^{1}$, \\ Roberto O. Castañeda-Arriola ${ }^{2}$, Juan J. Ojeda-Carrasco ${ }^{3}$, Guillermina Ávila-Ramírez ${ }^{4}$ \\ and Julio V. Figueroa-Millán $1, *$ (D)
}

check for updates

Citation: Lira-Amaya, J.J.; MartínezGarcía, G.; Santamaria-Espinosa, R.M.; Castañeda-Arriola, R.O.; Ojeda-Carrasco, J.J.; Ávila-Ramírez, G.; Figueroa-Millán, J.V. Comparative Study of Indirect Fluorescent Antibody, ELISA, and

Immunochromatography Tests for Serological Diagnosis of Bovine Babesiosis Caused by Babesia bovis. Animals 2021, 11, 3358. https:// doi.org/10.3390/ani11123358

Academic Editor: Abdul Jabbar

Received: 16 October 2021

Accepted: 22 November 2021

Published: 24 November 2021

Publisher's Note: MDPI stays neutral with regard to jurisdictional claims in published maps and institutional affiliations.

Copyright: (C) 2021 by the authors Licensee MDPI, Basel, Switzerland. This article is an open access article distributed under the terms and conditions of the Creative Commons Attribution (CC BY) license (https:/ / creativecommons.org/licenses/by/ $4.0 /)$.
1 Babesia Laboratory Unit, CENID-Salud Animal e Inocuidad, INIFAP, Carr. Fed. Cuernavaca-Cuautla No. 8534, Col. Progreso, Jiutepec 62550, Mexico; lira.juan@inifap.gob.mx (J.J.L.-A.); martinez.grecia@inifap.gob.mx (G.M.-G.); santamaria.rebeca@inifap.gob.mx (R.M.S.-E.)

2 La Posta Experimental Field, INIFAP, Carr. Fed. Veracruz-Cordoba Km. 22.5, Paso del Toro, Medellin 94277, Mexico; castaneda.roberto@inifap.gob.mx

3 UAEM University Center Amecameca, Autonomous University Mexico State, Carr. Amecameca-Ayapango Km. 2.5, Amecameca 56900, Mexico; jjojedac@uaemex.mx

4 Faculty of Medicine, National Autonomous University of Mexico, Circuito Escolar 411A, Copilco Universidad, Ciudad de México 04510, Mexico; guilleavila2000@yahoo.com

* Correspondence: figueroa.julio@inifap.gob.mx; Tel.: +52-777-320-5544

Simple Summary: Currently serological diagnosis of bovine babesiosis is based on the detection of Babesia-specific antibodies (immunoglobulin-G). Antibody detection is commonly used in seroepidemiological studies or in the assessment of antibabesial antibody titers after cattle vaccination. The indirect fluorescent antibody test (IFAT) and enzyme-linked immunosorbent assay (ELISA) are the most widely used diagnostic tests, although there their implementation has some drawbacks, principally due to the requirements for trained personnel, specific materials, and special laboratory equipment. This study compared a newly designed rapid immunochromatography test (ICT), which has been reported recently and used for Babesia bovis-specific antibody detection with promising results, with an in-house ELISA for the serological diagnosis of cattle exposed to B. bovis (Babesia bovis) in Mexico. Higher sensitivity and specificity values were found by ICT, proving its effectiveness over ELISA. ICT also had better concordance than ELISA when IFAT was used as the "gold standard". The rapid ICT was shown to have diagnostic utility for the detection of antibodies against $B$. bovis and could be used as a field test in Mexico due to its practicality, as it does not need laboratory equipment for implementation and interpretation of results.

Abstract: The indirect fluorescent antibody test (IFAT) is the most frequently used test to conduct seroepidemiological studies so far, and it is regarded as the "gold standard" test for the serological diagnosis of bovine babesiosis. The aim of the present study was to compare the enzyme-linked immunosorbent assay (ELISA) and the rapid immunochromatography test (ICT) for use in the serological diagnosis of cattle exposed to B. bovis in Mexico. The evaluation of test performance was carried out with 30 positive and 30 negative reference sera. A total of 72 bovine sera samples collected from cattle in a region with endemic bovine babesiosis were analyzed by ELISA and ICT, and the results were compared with those of IFAT. Kappa value (k) was also calculated to determine the agreement between tests. The sensitivity and specificity of ELISA for detecting antibodies against B. bovis were $87 \%(26 / 30)$ and $80 \%(24 / 30)$, respectively. The sensitivity and specificity of ICT for detecting antibodies against B. bovis were $90 \%(27 / 30)$ and $83.3 \%(25 / 30)$, respectively. The overall concordance determined for ELISA and ICT was 94.4\% (68/72) and 98.6\% (71/72), respectively, when the results were compared with those of IFAT. ICT was more sensitive and specific in this comparative study, showing good strength of agreement $(\mathrm{k}=0.79)$ with respect to IFAT. ICT combines a strip-based assay system that is fast, practical, and sensitive for detection of antibodies to B. bovis, which suggests that it could be applied in the field without requiring any laboratory equipment for its use and interpretation of test results. 


\section{Introduction}

Livestock production in Mexico is considered one of the main activities of the agrifood sector, ranking second only after crop production. The predominant system for meat and milk production in tropical and subtropical regions is extensive grazing [1]. Currently, the total cattle population in Mexico is estimated at 35.2 million head, contributing to the production of approximately 2 million tonnes of meat and 12.5 million liters of milk per year [2]. The occurrence of certain infectious diseases in cattle, including tick-borne diseases such as babesiosis, is a problem of great economic importance to the livestock industry [3].

Bovine babesiosis, especially caused by Babesia bovis and Babesia bigemina, is a tickborne hemoprotozoan disease that is widely distributed in tropical and subtropical regions all over the world. The infection is clinically characterized by fever, listlessness, hemoglobinuria, hemolytic anemia, and death in acute untreated cases [4]. In Mexico, the main vector of both Babesia species is the tick R. microplus [5]. Bovine babesiosis represents a limitation to development and productivity in tropical and subtropical livestock production regions all over the world [6]. The economic losses may be on the order of USD 10 billion per year worldwide [7], associated with low milk production and decline in daily weight gain of infected animals, along with the high costs of treatment and the application of control measures for tick vectors [8]. Currently, $75 \%$ of the cattle population raised in regions with a high incidence of R. microplus ticks in Mexico is at risk of becoming infected with $B$. bovis and B. bigemina $[8,9]$.

Routine laboratory diagnosis consists of identifying intraerythrocytic Babesia sp. forms during microscopic examination of Giemsa-stained blood smears [5]. Serological tests are commonly used to detect Babesia-specific antibodies in serum samples, such as the indirect immunofluorescence assay (IFAT) and enzyme-linked immunosorbent assay (ELISA) [10]. The IFAT is the most frequently used test in seroepidemiological studies and so far is regarded as the "gold standard" test for serological diagnosis of bovine babesiosis [11]. However, both serological tests have several limitations, as their implementation requires trained personnel and special laboratory material and equipment [12]. Recently, rapid immunochromatography tests (ICTs) have been reported to be effective when used for the detection of specific antibodies against B. bovis or B. bigemina in cattle [13-17]. The ICT is a rapid, membrane-based lateral flow immunoassay that does not require any laboratory equipment for result analysis and has been reported to have high diagnostic sensitivity. In addition, it has the great advantage that it can be used in clinical and field conditions directly on farms [12].

The aim of the present study was to compare the enzyme-linked immunosorbent assay (ELISA) and the rapid immunochromatography test (ICT) for use in serological diagnosis of cattle exposed to B. bovis in Mexico.

\section{Materials and Methods}

\subsection{Sample Size Calculation}

The sample size of the cattle population was determined according to the mathematical formula described for research studies [18] using the Raosoft ${ }^{\circledR}$ program (freely available online: http:/ / www.raosoft.com/samplesize.html accessed on 1 July 2020). The formula $\mathrm{n}=\left[\mathrm{N}\left(\mathrm{Z}^{2}\right) \times \mathrm{p}(1-\mathrm{p})\right] /\left[\mathrm{d}^{2}(\mathrm{~N}-1)+\left(\mathrm{Z}^{2}\right) \mathrm{p}(1-\mathrm{p})\right]$ was applied, where $\mathrm{n}$ is the required sample size, $\mathrm{N}$ is the population size, $\mathrm{Z}$ is the confidence value $(95 \%), \mathrm{p}$ is the approximate prevalence, and $\mathrm{d}$ is the absolute accuracy level (5\%). The approximate prevalence for the sampled area was $80 \%$, as previously reported in a study performed in Chiapas State, Mexico [19]. 


\subsection{Serum Samples}

\subsubsection{Reference Serum Samples}

Positive and negative serum samples classified by IFAT were used to perform the evaluation using ELISA, ICT, and IFAT. Thirty Babesia sp.-negative serum samples were collected from cattle born and raised in Amecameca municipality, State of Mexico, Mexico (2420 m above sea level, sub-humid temperate climate), considered a naturally Rhipicephalus (Boophilus) tick-free area and, therefore, a Babesia-free area [20,21]. Thirty B. bovis-positive serum samples from dual-purpose cattle in an area with endemic bovine babesiosis in Paso del Toro, Veracruz, Mexico (10 m above sea level, tropical climate conditions) [5]. The reference serum samples were used to assess the performance of ELISA, ICT, and IFAT.

\subsubsection{Field Serum Samples}

Blood samples from 72 cattle were collected at a farm located in a babesiosis endemic area (Pichucalco, Chiapas, Mexico). The serum was separated immediately by centrifugation, and then stored in aliquots at $-20^{\circ} \mathrm{C}$ until use. The serum samples were used to estimate the degree of agreement between ELISA and ICT and compare those against IFAT.

\subsection{Pre-Adsorption of Serum Samples}

To avoid nonspecific antibody binding in the tests, all serum samples were subjected to a pre-adsorption process with $E$. coli cell lysate, as described previously [22,23]. Briefly, $200 \mu \mathrm{L}$ of E. coli TOP10 (uninduced) cells cultured in LB medium and stored at $-80^{\circ} \mathrm{C}$ were resuspended in $1 \mathrm{~mL}$ of phosphate-buffered saline (PBS) containing $500 \mu \mathrm{L}$ acid-washed glass beads (Sigma-Aldrich, St. Louis, MO, USA). Then, the suspension was homogenized using a mechanical shaker for $30 \mathrm{~s}$ at maximum speed and immediately placed on ice for $30 \mathrm{~s}$; these steps were repeated until 8 cycles were completed. Subsequently, the lysate suspension was centrifuged at $18,620 \times g$ for $8 \mathrm{~min}$ at room temperature and the supernatant was separated from the pellet for use in the assay. The ELISA microplates were coated with $50 \mu \mathrm{L}(100 \mu \mathrm{g} / \mathrm{mL})$ of E. coli lysate suspension and prepared as described in Section 2.4. The serum samples were added to the ELISA microplates and incubated for $30 \mathrm{~min}$ at $37^{\circ} \mathrm{C}$, then transferred to another ELISA microplate, which has been previously coated with the lysate, and the microplates were incubated again for $30 \mathrm{~min}$ at $37^{\circ} \mathrm{C}$. The absorbed serum samples were recovered and stored in aliquots at $-20^{\circ} \mathrm{C}$ until analysis.

\subsection{Preparation of Recombinant Protein MSA-1 and Sheep Anti-rMSA-1 IgG}

Babesia bovis recombinant merozoite surface antigen 1 (rMSA-1) was expressed and prepared as previously described [24]. Briefly, transformed E. coli TOP10 cells containing the recombinant pBAD/ThioTOPO ${ }^{\circledR}$, (ThermoFisher Scientific, Waltham, MA, USA) plasmid inserted with the $m s a-1$ gene were resuspended in lysis solution containing sarcosyl $(0.03 \%)$ and protease inhibitors DNase and RNase and incubated for $3 \mathrm{~h}$ at room temperature with gentle agitation. The recombinant $B$. bovis MSA-1 protein was recovered using a ProBond Purification System on nickel-charged Ni-NTA affinity resin (ThermoFisher Scientific, Waltham, MA, USA) according to the manufacturer instructions, and purification quality was analyzed by electrophoresis in $12 \%$ polyacrylamide gels $[10,24]$. Finally, the rMSA-1 was dialyzed against PBS (pH 7.4) and concentrated using Amicon 50K MWCO filters (Corning, Tewksbury, MA, USA). Four male Pelibuey sheep ( $>12$ months of age) were immunized with $500 \mu \mathrm{g}$ of rMSA-1 mixed with an equal volume $(v / v)$ of Montanide ISA 70VG adjuvant (SEPPIC, Fairfield, NJ, USA) by administration of 5 subcutaneous injections into the scapular area at 14-day intervals. Total IgG was purified from sheep serum with Protein G Sepharose (Sigma-Aldrich) according to the manufacturer's instructions. The concentration and dialysis procedures for sheep anti-rMSA-1 IgG were the same as those performed for rMSA-1. 


\subsection{Enzyme-Linked Immunosorbent Assay (ELISA)}

The test was performed similarly to the established protocol described previously [25] with slight modifications. For this test, 96-well ELISA microplates (Corning, Tewksbury, MA, USA) were coated with $50 \mu \mathrm{L}$ of rMSA- $1(1.8 \mu \mathrm{g} / \mathrm{mL})$ diluted in carbonate/bicarbonate buffer (pH 9.6) (Sigma-Aldrich) and incubated at $4{ }^{\circ} \mathrm{C}$ overnight. The ELISA microplates were blocked with $50 \mu \mathrm{L} /$ well of $5 \%$ skim milk in PBS-0.1\% Tween 20. Triplicates containing $50 \mu \mathrm{L} /$ well of the pre-adsorbed serum samples (1:200 dilution in PBS) were added and microplates were incubated for 1 hour at $37^{\circ} \mathrm{C}$. Then, $50 \mu \mathrm{L}$ of rabbit anti-IgG bovine conjugated with horseradish peroxidase (1:10,000 dilution in PBS) was added to each well and incubated for $30 \mathrm{~min}$ at $37^{\circ} \mathrm{C}$. Tetramethylbenzidine substrate (Sigma-Aldrich) was then added to each well of the ELISA microplates (50 $\mathrm{L}$ /well). After $30 \mathrm{~min}$ at $37^{\circ} \mathrm{C}$ incubation, the absorbance value was determined using an iMARK microplate reader (Bio-Rad, Hercules, CA, USA) with a $650 \mathrm{~nm}$ filter. During the procedure, the microplates were washed 3 times between each step with PBS $0.1 \%$ Tween 20, except after the substrate was added. The results, obtained as optical density (OD) absorbance values for each serum sample, were expressed as a positivity index (PI) according to the following formula: $\mathrm{PI}=$ average OD each serum/average OD negative control +3 standard deviations; serum with a PI value $\geq 1$ was considered as positive and $\mathrm{PI}<1$ as negative for antibodies against B. bovis.

\subsection{Immunochromatographic Test (ICT)}

The bioconjugate was prepared by gently mixing B. bovis rMSA-1 $(90 \mu \mathrm{g} / \mathrm{mL})$ with $50 \mathrm{~nm}$ gold colloid nanoparticles (Ted Pella Inc., Redding, CA, USA) at a 1:10 volume ratio and then incubated for $2 \mathrm{~h}$ at room temperature with agitation (100 rpm). Subsequently, $1 \mathrm{~mL}$ of $20 \mathrm{mM}$ borate buffer at $\mathrm{pH} 7.4$ containing $1 \%$ bovine serum albumin (BSA) was added to stabilize and block the bioconjugate nanoparticles. After centrifugation for $30 \mathrm{~min}$ at $18,620 \times g$, the supernatant was discarded and the pellet was resuspended in $1 \mathrm{~mL}$ of $20 \mathrm{mM}$ borate buffer at $\mathrm{pH} 7.4$ containing $1 \%$ BSA. The suspension was centrifuged again for $30 \mathrm{~min}$ at $18,620 \times g$ and the resulting pellet was resuspended in $200 \mu \mathrm{L}$ of resuspension buffer for bioconjugate $(1 \%(w / v)$ BSA, $0.02 \mathrm{M}(w / v)$ Tris base, $0.003 \mathrm{M}(w / v)$ sodium azide, and $20 \%(w / v)$ sucrose). rMSA-1 $(1100 \mu \mathrm{g} / \mathrm{mL})$ and sheep anti-rMSA-1 $\operatorname{IgG}(8700 \mu \mathrm{g} / \mathrm{mL})$ were linearly jetted onto a test line and control line, respectively, of a nitrocellulose membrane with a plastic backing (Millipore, Burlington, MA, USA) using a XYZ3210 dispensing platform (BioDot, Irvine, CA, USA). Then, the membrane was dried for $30 \mathrm{~min}$ at $45^{\circ} \mathrm{C}$ and cut in $4 \mathrm{~mm}$ wide strips using a CM5000 guillotine cutter (BioDot, Irvine, CA, USA)). The bioconjugate pads were manually impregnated with $4 \mu \mathrm{L}$ of the bioconjugate and then dried for $30 \mathrm{~min}$ at $42{ }^{\circ} \mathrm{C}$. Assembly of the strips was carried out as previously described [26], by attaching the nitrocellulose membrane, sample pad, bioconjugate pad (glass fiber), and absorbent pad slightly overlapping each part. The test was performed by adding $10 \mu \mathrm{L}$ of pre-adsorbed serum on the sample pad, which was previously activated with a solution containing $0.05 \mathrm{M}(w / v)$ Tris base, $0.5 \%(w / v)$ casein, $1 \%(w / v)$ polyvinylpyrrolidone (PVP), and $0.05 \%(v / v)$ Tween 20 , followed by $100 \mu \mathrm{L}$ of the running buffer solution (PBS at pH 7.6 with $1.7 \%(w / v)$ BSA and $3 \%(v / v)$ Tween 20). The result for detection of antibodies to $B$. bovis was visually interpreted 10 min after sample addition based on the appearance of one colored band at a control line (negative) and two colored bands (positive) at control and test lines. Any other result was considered an invalid test [27].

\subsection{Indirect Fluorescent Antibody Test (IFAT)}

Microscope slides of $B$. bovis-infected erythrocytes derived from in vitro culture were used as antigen [7]. The slides were dried in silica beads for $30 \mathrm{~min}$ at $37^{\circ} \mathrm{C}$ and subsequently fixed with acetone for $10 \mathrm{~min}$. Then $10 \mu \mathrm{L}$ of the pre-adsorbed serum samples (1:80 dilution in PBS) was placed on the slides and incubated for $30 \mathrm{~min}$ at $37^{\circ} \mathrm{C}$, followed by 3 washes with PBS in gentle agitation for 5 min each. Then, $10 \mu \mathrm{L}$ of goat anti-IgG bovine 
conjugated with fluorescein isothiocyanate (diluted 1:1600 in PBS) was added to each sample and washed as described above. Finally, the slides were mounted and visualized with a Leica DMLB epifluorescence microscope (Leica, Wetzlar, Germany) using a 100× objective.

\subsection{Statistical Analysis}

The performance of ELISA, ICT, and IFAT was evaluated in terms of sensitivity, specificity, positive predictive value (PPV), negative predictive value (NPV), positive likelihood ratio (+LR), negative likelihood ratio (-LR), and kappa value with 95\% confidence interval (CI) using the VassarStats program (freely available online: http:/ /vassarstats.net/ accessed on 1 February 2021). The strength of agreement with kappa values was interpreted as poor, <0.20; fair, 0.21 to 0.40 ; moderate, 0.41 to 0.60 ; good, 0.61 to 0.80 ; or very good, $0.81-1.00[15,28]$. The diagnostic utility of the tests was measured according to the $+\operatorname{LR}(>1)$ and - LR $(<0.1)$ values, and was considered as highly relevant, good, fair, or poor [29].

\subsection{Ethical Statement}

The cattle were immobilized ( $<5 \mathrm{~min})$ in a cattle crusher to collect the blood samples. Animal handling was conducted in accordance with Mexican regulation NOM-062-ZOO1999 regarding technical specifications for production, care, and use of laboratory animals.

\section{Results}

\subsection{Performance Evaluation of ELISA and ICT}

The results obtained in the performance evaluation of tests are shown in Table 1 . The sensitivity and specificity of ELISA for detection of antibodies to B. bovis (Figure 1) were 87\% (95\% CI: 68.3-95.6\%) and 80\% (95\% CI: 60.8-91.5\%) and the probability of getting a positive (PPV) or negative (NPV) result using the test was $81.2 \%$ and $85.7 \%$, respectively. Similarly, the ICT for detection of antibodies to B. bovis (Figure 2) showed a sensitivity of 90\% (95\% CI: 72.3-97.3\%) and a specificity of 83.3\% (95\% CI: 64.5-93.6\%), with a probability of PPV and NPV at $84.3 \%$ and $89.2 \%$, respectively.

Table 1. Results of The enzyme-linked immunosorbent assay (ELISA), immunochromatography test (ICT), and indirect fluorescent antibody test (IFAT) for detection of antibodies against B. bovis in reference serum samples.

\begin{tabular}{cccc}
\hline \multirow{2}{*}{ Result } & & \multicolumn{3}{c}{ Reference Serum Samples } \\
\cline { 2 - 5 } & & B. bovis-Positive Serum $(\mathbf{n}=\mathbf{3 0})$ & Babesia spp.-Negative Serum (n = 30) \\
\hline \multirow{2}{*}{ ELISA } & + & 26 & 6 \\
& - & 4 & 24 \\
\hline \multirow{2}{*}{ ICT } & + & 27 & 25 \\
& - & 3 & 8 \\
\multirow{2}{*}{ IFAT } & + & 27 & 22 \\
\hline
\end{tabular}

Note: Positive (+) and negative (-) results of each test are shown.

\subsection{Comparison between ELISA and ICT for Detection of Antibodies to B. bovis}

The test showing the highest number of positive results for detection of antibodies to B. bovis in field serum samples was the ICT one (Table 2). The ICT detected antibodies in 70 serum samples $(97.2 \%)$, including one sample that was negative by IFAT. Three serum samples were negative by IFAT and ELISA, but four samples that were negative by ELISA were positive by IFAT (Table 3). When the results of ELISA and ICT were compared with those of IFAT, the overall concordance was $94.4 \%(68 / 72)$ and $98.6 \%(71 / 72)$, respectively. The sensitivity was $94.2 \%(65 / 69)$ and $100 \%(69 / 69)$, and the specificity was $100 \%(3 / 3)$ and $66.6 \%(2 / 3)$, respectively (Table 4$)$. The strength of agreement with respect to IFAT was moderate for ELISA $(k=0.57)$ and good for ICT $(k=0.79)$. ELISA and ICT showed fair 
and good diagnostic utility, respectively, according to the interpretation of $+\mathrm{RV}$ and $-\mathrm{RV}$ values (Table 4 ).
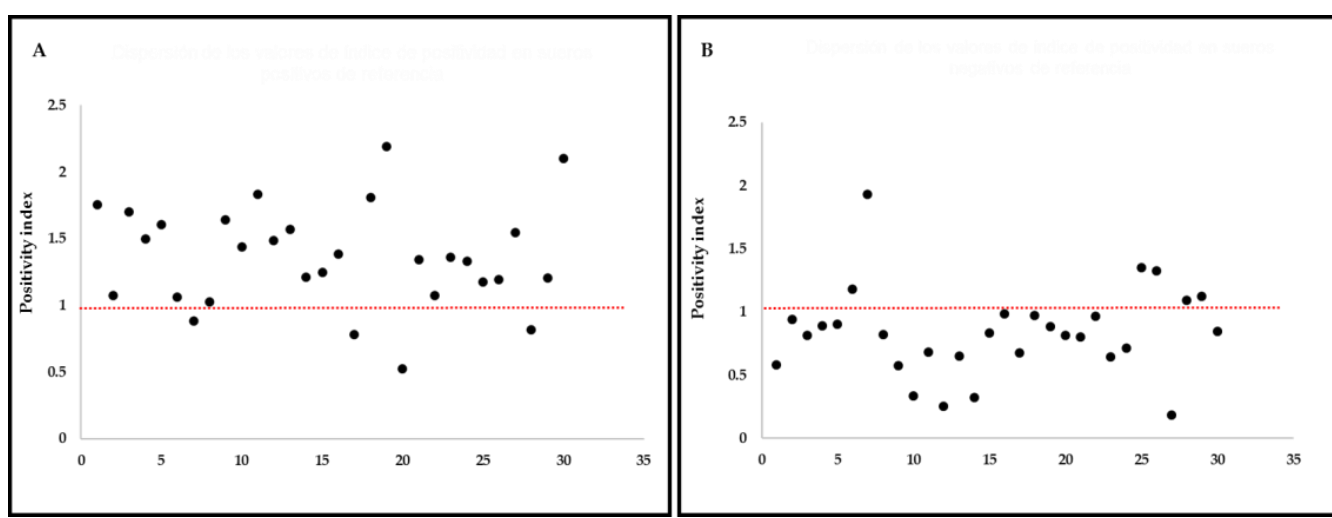

Figure 1. Scatter chart of values according to positivity index for each serum sample in ELISA: (A) 30 B. bovis-positive cattle serum samples and (B) 30 Babesia sp.-negative samples compared to IFAT; samples were considered positive by ELISA at a positivity index $>1$ and negative at $<1$, respectively.

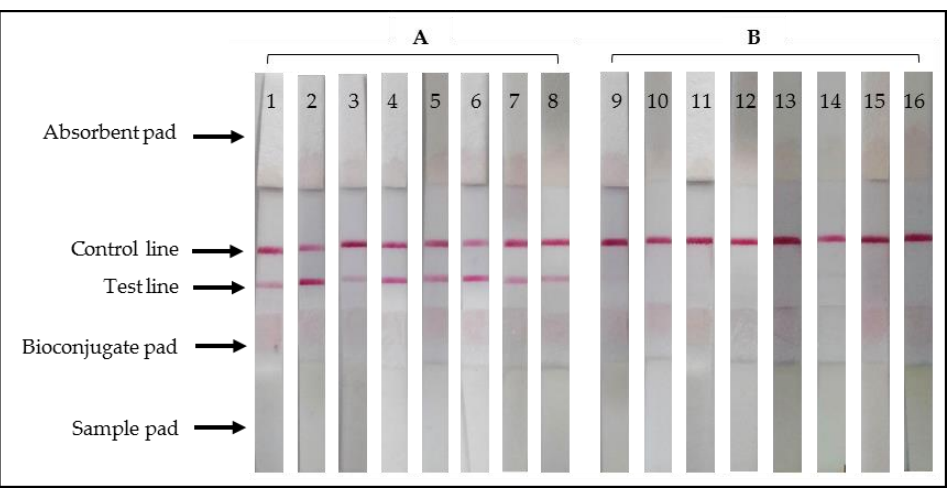

Figure 2. ICT strips used for detection of antibodies to B. bovis: examples after applying (A) positive and (B) negative reference bovine serum samples. Lanes 1-8, positive result for detection of antibodies to $B$. bovis (colored bands at control and test lines); lanes 9-16, negative result (colored band at control line).

Table 2. Results of the ELISA, ICT and IFAT for detection of antibodies to B. bovis in field serum samples.

\begin{tabular}{ccccccc}
\hline \multirow{2}{*}{$\operatorname{Result}^{\mathbf{c}}$} & \multicolumn{2}{c}{ ELISA } & \multicolumn{2}{c}{ ICT } & \multicolumn{2}{c}{ IFAT } \\
\cline { 2 - 7 } & $\mathbf{n}$ & $\mathbf{\%}^{\mathbf{b}}$ & $\mathbf{n}^{\mathbf{a}}$ & $\mathbf{\%} \mathbf{b}$ & $\mathbf{n}^{\mathbf{a}}$ & $\mathbf{\%}^{\mathbf{b}}$ \\
\hline+ & 65 & 90.3 & 70 & 97.2 & 69 & 95.8 \\
- & 7 & 9.7 & 2 & 2.8 & 3 & 4.2 \\
Total & 72 & 100 & 72 & 100 & 72 & 100 \\
\hline
\end{tabular}

a Number of serum samples analyzed. ${ }^{\mathrm{b}}$ Percentage of total number of serum samples analyzed. ${ }^{\mathrm{c}}$ Positive (+) and negative $(-)$ result.

Table 3. Comparison of IFAT with ELISA and ICT for detection of antibodies to B. bovis in field serum samples.

\begin{tabular}{|c|c|c|c|c|c|}
\hline \multirow{2}{*}{ Result IFAT $^{c}$} & \multicolumn{2}{|c|}{ ELISA $^{a}$} & \multicolumn{2}{|c|}{$\mathrm{ICT}^{\mathrm{b}}$} & \multirow{2}{*}{ Total } \\
\hline & + & - & + & - & \\
\hline+ & 65 & 4 & 69 & 0 & 69 \\
\hline- & 0 & 3 & 1 & 2 & 3 \\
\hline Total & 65 & 7 & 70 & 2 & 72 \\
\hline
\end{tabular}

${ }^{a}$ Positive (+) and negative (-) result using ELISA test. ${ }^{b}$ Positive $(+)$ and negative (-) result using ICT test. ${ }^{c}$ Positive $(+)$ and negative $(-)$ result using IFAT test. 
Table 4. Overall results of ELISA and ICT for detection of antibodies to B. bovis in field serum samples compared with those of IFAT.

\begin{tabular}{ccc}
\hline & \multicolumn{2}{c}{ IFAT Results Compared to } \\
\cline { 2 - 3 } Terms Evaluated & ELISA & ICT \\
\hline Sensitivity (\%) & 94.2 & 100 \\
Specificity (\%) & 100 & 66.6 \\
Concordance (\%) & 94.4 & 98.6 \\
Kappa value & 0.57 & 0.79 \\
+LR & 4.3 & 5.4 \\
-LR & 0.16 & 0.12 \\
\hline
\end{tabular}

\section{Discussion}

Different tests have been described and used routinely for the detection of specific antibodies in cattle after exposure to Babesia sp. [7,30]. These tests are not useful for diagnosing bovine babesiosis during the clinical phase of the disease but are used for epidemiological studies or to evaluate antibabesial antibody titers after cattle vaccination $[4,7,24,30,31]$. The IFAT provides adequate sensitivity and is easy to perform [12]; however, it has some disadvantages in the analysis of samples, such as the low number that can be performed per day, depending on the operator's ability and expertise, and the results are influenced by the subjective judgment of the analyst [32]. ELISA allows processing of a higher number of samples in a working day, and since it is an automated method, another advantage is the objectivity of the results interpretation [12]. Among the main disadvantages of ELISA is that the procedure involves several steps for execution, which makes it costly, and like IFAT, it requires special laboratory equipment for sample analysis and result interpretation [14]. Recently, the development of new and innovative diagnostic methods, such as an immunochromatography test (ICT) based on a lateral flow membrane, have changed the landscape for users, facilitating the detection of antibodies or soluble antigens $[33,34]$. These tests provide specific results in a timely manner and a short time, and they can be applied in laboratories, veterinary clinics, or directly on farms without the need for any equipment to detect or display the results of the assay [35].

In the current study, a comparison of ELISA and ICT with IFAT was performed to assess their feasibility for wider use in the serological diagnosis of cattle exposed to $B$. bovis in Mexico. The evaluation of ELISA performance showed that the sensitivity and specificity rates for detecting antibodies against $B$. bovis were 87 and $80 \%$, respectively. The sensitivity and specificity of an indirect ELISA instrumented in Mexico and based on B. bovis recombinant merozoite surface antigen 1 (MSA-1) were 80 and 97\%, respectively [36]. The ELISA in this study was performed as described previously [36]; however, some modifications were made, including the use of a different set of positive and negative control sera and a different rMSA- 1 antigen batch, and replacement of commercial goat serum (anti-IgG bovine) conjugated with alkaline phosphatase (ALP) by commercial rabbit serum (anti-IgG bovine) conjugated with horseradish peroxidase (HRP).

The sensitivity and specificity rates reported in the current study are slightly lower compared with those described in a study using ELISA with a B. bovis chimerical multiantigen (rMABbo-ELISA), which achieved sensitivity and specificity values of $95.9 \%$ and $94.3 \%$, respectively. Such values may be due to the number of antigenic determinants containing the three B. bovis antigens that were used Merozoite Surface Antigen-2c (MSA2c), Rhoptry-Associated Protein-1 (RAP-1), and heat shock protein 20), which would increase the probability for antibody recognition of B. bovis antigens [22]. Another study using more than one antigen (rBbSBP- $1+\mathrm{rBbSBP}-4)$ in an indirect ELISA demonstrated the usefulness of this method for the detection of antibodies against $B$. bovis in cattle compared to results using a single antigen (rBbSBP-1 or rBbSBP-4) [37].

After evaluating the ICT performance in the present study, the specificity rate turned out to be slightly low $(83.3 \%)$ when compared to that obtained in the evaluation of Bovis ImmunoChromatography Test (BoICT) $(93.8 \%)$ based on B. bovis recombinant MSA-2c 
antigen [13]. The sensitivity rate of the ICT $(90 \%)$ is consistent with values reported previously for other developed ICT diagnostic tests for infectious diseases caused by protozoan parasites, with sensitivity rates ranging from 83.3 to $100 \%$ [27,38-40]. The results presented in our study demonstrate that ICT was more sensitive ( $90 \%$ vs. $87 \%$ ) and showed greater specificity ( $83.3 \%$ vs. $80 \%$ ) than ELISA for serological diagnosis. As an explanation for the high number of false positives found in both tests (5/30 and 6/30, respectively) regarding the number of samples, comparing to the values reported for BoICT and Bovis EnzymeLinked ImmunoSorbent Assay (BoELISA) (5/80 and 4/80, respectively) [13] suggests that the MSA-1 antigen may not be as specific as the MSA-2c antigen for the detection of antibodies against $B$. bovis [41]. It was shown that immunization with a recombinant MSA-1 antigen induced a humoral immune response in cattle [30,42]. Also, specific antibodies against the MSA- 1 antigen have been used to assess the in vitro neutralization merozoite invasion of strains of B. bovis from Mexico and Texas [43]. Moreover, immunoblotting assays showed cross-reactivity of MSA-1-specific monoclonal antibodies with protein extracts of B. bovis-infected erythrocytes from isolates from different regions of Mexico [41]. At present, there is no report on the identification of the orthologous protein of the MSA- 1 antigen in protozoan parasites other than B. bovis. However, the possibility of cross-reactivity by antibodies against other apicomplexan parasites, such as N. caninum and T. gondii, for example, cannot be totally dismissed, since this may be the case for the reference bovine serum samples used in the current study, as has been previously described [20,44,45].

The ICT was the most successful test for detecting antibodies against B. bovis in field serum samples, showing an overall concordance of $98.6 \%$ compared with the IFAT. In a similar study, the concordance of ICT in detecting antibodies against $B$. bovis using the C-terminal truncated portion of the B. bovis rhoptry-associated protein 1 (rRAP-1/CTs) was 90.3 and $92.5 \%$ compared to the reference standard assays IFAT and ELISA, respectively [26]. The seroprevalence of B. bovis by ELISA and ICT ( 90.3 and $97.2 \%$, respectively) in the current study was higher compared to that documented in other seroepidemiological studies, where the recombinant spherical body protein 4 (SBP-4) of B. bovis was used as antigen in the tests (ELISA and ICT). SBP-4 is found in vast quantities in the cytoplasm and is released when merozoites egress from the erythrocyte.

The seroprevalence rates in Uganda using ELISA and ICT based on SBP-4 protein were 6.2 and $4.3 \%$, respectively [14], whereas in Indonesia, Babesia prevalence rates were 69.8 and $65.1 \%$, and other studies reported seroprevalence rates of $28.4 \%$ and $25.3 \%$, respectively $[15,17]$. In Argentina, using only the ICT, the determined seroprevalence of $B$. bovis was $71.3 \%$ [16]. This notable difference could be because greater numbers of samples were used in those, collected in different regions of the respective countries, as compared to the 72 samples collected in a single region evaluated in the current study, in addition to the difference in breeds of cattle sampled.

When ICT and IFAT results were compared to determine the concordance rate, out of the 72 samples collected at the Pichucalco Experimental Station, 69 were positive in IFAT and 70 were positive in ICT. With these data, the calculated sensitivity and specificity were $100 \%(69 / 69)$ and $66 \%(2 / 3)$, respectively. Possible explanations for the low specificity $(66 \%)$ of ICT compared to IFAT in terms of concordance, even when serum samples were pre-absorbed with E. coli lysates, may be: (a) the presence of a high titer of E. coli-reacting antibodies present in the sample, which, despite pre-absorption, remained in the sample, or (b) the presence of cross-reacting antibodies present in samples from cattle previously exposed to, for example, B. bigemina, another Babesia sp. prevalent in endemic bovine babesiosis areas [25]. This was particularly the case, as the individual was also positive by IFAT when B. bigemina infected erythrocytes were used as antigen.

According to the concordance between ELISA and ICT, the highest kappa value calculated in the current study was for ICT (0.79), a similar value to that of bovis ImmunoChromatography Test (bovICT) $(>0.7)$, used to detect antibodies against $B$. bovis in bovine serum samples collected in the field $[12,15,17]$. The likelihood ratio (LR) is a very useful tool for decision-making when evaluating the performance of a diagnostic test. The 
interpretation of the LR+ and LR - values indicated that the diagnostic utility of the tests for the serological diagnosis of bovine babesiosis was good for ICT and fair for ELISA according to the scale reported previously by Silva and Molina (2016). In these terms, ICT showed more satisfactory results (5.4 and 0.12 , respectively) compared with ELISA (4.3 and $0.16)$, where $\mathrm{LR}+(>1)$ and $\mathrm{LR}-(<0.1)$ indicate the diagnostic utility and how appropriate the test might be [29].

\section{Conclusions}

The current study showed that, compared to ELISA, the ICT test showed higher sensitivity, concordance, and diagnostic utility for the detection of antibodies to B. bovis. The ICT combines a fast and practical strip-based system, which could be used by technical personnel and veterinarians as a field test for the serodiagnosis of bovine babesiosis in Mexico. The ICT does not require any laboratory equipment, as it can be performed practically on the livestock premises, and the interpretation of test results can be visualized very fast. However, further optimization is recommended to improve the specificity of ICT based on the B. bovis rMSA-1 antigen. In order to solve the low specificity of ICT caused by the possible presence of $E$. coli proteins in the test's gold conjugate, giving rise to potential nonspecific reactions, further purification of recombinant MSA-1 antigen produced in E. coli cells should be attempted using other immunoaffinity purification methods with anti-MSA-1-specific antibodies. Better yet, the recombinant protein should be produced in a eukaryotic expression system that releases or secretes it in soluble form in the culture medium, allowing easier protein purification and concentration using, for example, the Pichia pastoris expression system. Also, further prevalence studies, including larger numbers of cattle, various cattle production units, and different geographic regions in Mexico, are required to validate the ELISA and ICT.

Author Contributions: Conceptualization, J.J.L.-A. and J.V.F.-M.; Formal analysis, J.J.L.-A. and J.V.F.-M.; Writing—original draft preparation J.J.L.-A., G.M.-G., R.M.S.-E., R.O.C.-A., G.Á.-R. and J.J.O.-C.; Writing-review and editing, J.J.L.-A. and J.V.F.-M.; Project administration, J.V.F.-M.; Funding acquisition, J.V.F.-M. All authors have read and agreed to the published version of the manuscript.

Funding: This study was funded by Consejo Nacional de Ciencia y Tecnología (CONACYT) and INIFAP through projects PDCPN 2015_1336, A1-S-43508, and 1672534936.

Institutional Review Board Statement: Animals used were not from farms, they belong to the cattle production unit at the Pichucalco Research Experimental Station, which is part of a federal government institution, the Instituto Nacional de Investigaciones Forestales, Agricolas y Pecuarias (INIFAP) in Mexico.

Data Availability Statement: All data are contained within the paper.

Acknowledgments: The authors sincerely thank INIFAP and CONACYT in Mexico for providing financial support for research projects in the babesia laboratory unit at (formerly) CENID-Parasitologia Veterinaria, now part of CENID-Salud Animal e Inocuidad (National Research Center on Animal Health and Safety). The first author (José J. Lira-Amaya) gratefully acknowledges scholarship No. 703681 from CONACYT to pursue his postgraduate studies.

Conflicts of Interest: The authors declare no conflict of interest.

\section{References}

1. Urdaneta, F. Improving the productive efficiency of dual-purpose cattle farming systems (Taurus-Indicus). Arch. Latinoam. Prod. Anim. 2009, 17, 109-120. Available online: http:/ / www.bioline.org.br/pdf?la09016 (accessed on 1 February 2021).

2. SIAP. Available online: https://www.gob.mx/siap/acciones-y-programas/produccion-pecuaria (accessed on 7 April 2021).

3. Jongejan, F.; Uilenberg, G. The global importance of ticks. Parasitology 2004, 129, S3-S14. [CrossRef]

4. Bock, R.; Jackson, J.; de vos, A.; Jorgensen, W. Babesiosis of cattle. Parasitology 2004, 129, S247-S269. [CrossRef] [PubMed]

5. Bautista-Garfias, C.R.; Castañeda-Arriola, R.O.; Álvarez-Mártínez, J.A.; Rojas-Martínez, C.; Figueroa-Millán, J.V.; RodríguezLozano, A. The simultaneous vaccination of bovines with Lactobacillus casei and the bivalent vaccine against bovine babesiosis induces a better protection against Babesia bovis and B. bigemina transmitted by ticks in extreme field conditions. Vet. Méx. 2012, 43, 189-200. Available online: http:/ / www.scielo.org.mx/pdf/vetmex/v43n3/v43n3a1.pdf (accessed on 1 February 2021). 
6. Gohil, S.; Herrmann, S.; Gunther, S.; Cooke, B.M. Bovine babesiosis in the 21st century: Advances in biology and functional genomics. Int. J. Parasitol. 2013, 43, 125-132. [CrossRef]

7. Rojas, M.C.; Rodríguez, V.R.I.; Figueroa, J.V.; Bautista, G.C.R.; Castañeda, A.R.O.; Lira, A.J.J.; Vargas, U.P.; Ojeda, C.J.J.; Álvarez, J.A. Bovine babesiosis: Cattle protected in the field with a frozen vaccine containing Babesia bovis and Babesia bigemina cultured in vitro with a serum-free medium. Parasitol. Int. 2018, 67, 190-195. [CrossRef] [PubMed]

8. Rodríguez, V.R.I.; Grisi, L.; Pérez de León, A.A.; Silva, V.H.; Torres, A.J.F.J.; Fragoso, S.H.; Romero, S.D.; Cruz, R.R.; Saldierna, F.; García, C.D. Potential economic impact assessment for cattle parasites in Mexico. Rev. Mex. Cienc. Pecu. 2017, 8, 61-74. [CrossRef]

9. Romero-Salas, D.; Mira, A.; Mosqueda, J.; García, V.Z.; Hidalgo, R.M.; Ortiz, V.N.A.; Pérez, L.A.A.; Florin, C.M.; Schnittger, L. Molecular and serological detection of Babesia bovis and Babesia bigemina infection in bovines and water buffaloes raised jointly in an endemic field. Vet. Parasitol. 2016, 217, 101-107. [CrossRef]

10. Terkawi, M.A.; Alhasan, H.; Huyena, N.X.; Sabagh, A.; Awier, K.; Cao, S.; Goo, Y.K.; Aboge, G.; Yokoyama, N.; Nishikawa, Y.; et al. Molecular and serological prevalence of Babesia bovis and Babesia bigemina in cattle from central region of Syria. Vet. Parasitol. 2012, 187, 307-311. [CrossRef]

11. OIE. Bovine Babesiosis-OIE-World Organisation for Animal Health. Available online: https://www.oie.int/en/disease/bovinebabesiosis / (accessed on 8 June 2021).

12. Alvarez, J.A.; Rojas, C.; Figueroa, J.V. Diagnostic tools for the identification of Babesia sp. in persistently infected cattle. Pathogens 2019, 8, 143. [CrossRef]

13. Kim, C.M.; Conza, B.L.B.; Alhassan, A.; Iseki, H.; Yokoyama, N.; Xuan, X.; Igarashi, I. Development of a rapid immunochromatographic test for simultaneous serodiagnosis of bovine babesiosis caused by Babesia bovis and Babesia bigemina. Am. J. Trop. Med. Hyg. 2008, 78, 117-121. [CrossRef] [PubMed]

14. Stuart, T.D.; Magdy, B.A.; El-Saber, B.G.; Komugisha, M.; Joseph, B.; Vudriko, P.; Yahia, R.; Alkazmi, L.; Hetta, H.F.; Yokoyama, N.; et al. Assessing the immunochromatographic test strip for serological detection of bovine babesiosis in Uganda. Microorganisms 2020, 8, 1110. [CrossRef] [PubMed]

15. Guswanto, A.; Allamanda, P.; Mariamah, E.S.; Sodirun, S.; Wibowo, P.E.; Indrayani, L.; Nugroho, R.S.; Wirata, I.K.; Jannah, N.; Dias, L.P.; et al. Molecular and serological detection of bovine babesiosis in Indonesia. Parasit. Vectors 2017, 10, 550. [CrossRef]

16. Ganzinelli, S.; Benitez, D.; Gantuya, S.; Guswanto, A.; Florin-Christensen, M.; Schnittger, L.; Igarashi, I. Highly sensitive nested PCR and rapid immunochromatographic detection of Babesia bovis and Babesia bigemina infection in a cattle herd with acute clinical and fatal cases in Argentina. Transbound. Emerg. Dis. 2020, 67 (Suppl. S2), 159-164. [CrossRef] [PubMed]

17. Guswanto, A.; Allamanda, P.; Mariamah, E.S.; Munkjargal, T.; Tuvshintulga, B.; Takemae, H.; Sivakumar, T.; AbouLaila, M.; Terkawi, M.A.; Ichikawa-Seki, M.; et al. Evaluation of immunochromatographic test (ICT) strips for the serological detection of Babesia bovis and Babesia bigemina infection in cattle from Western Java, Indonesia. Vet. Parasitol. 2017, 239, 76-79. [CrossRef]

18. Miot, H.A. Sample size in clinical and experimental trials. J. Vasc. Bras. 2011, 10, 275-278. Available online: https:/ /www.scielo. $\mathrm{br} / \mathrm{j} / \mathrm{jvb} / \mathrm{a} / \mathrm{Dxg} 84 \mathrm{WBMPnNrVcpKMXyVfHd} /$ ?format=pdf\&lang=en (accessed on 1 February 2021). [CrossRef]

19. Ojeda, J.J.; Orozco, L.; Flores, R.; Rojas, C.; Figueroa, J.V.; Álvarez, M.J.A. Validation of an attenuated live vaccine against babesiosis in native cattle in an endemic area. Transbound. Emerg. Dis. 2010, 57, 84-86. [CrossRef]

20. Ojeda, C.J.J.; Espinosa, A.E.; Hernández, G.P.A.; Rojas, M.C.; Álvarez, M.J.A. Seroprevalencia de enfermedades que afectan la reproducción de bovinos para leche con énfasis en neosporosis. Ecosistemas Recur. Agropecu. 2016, 3, 243-249. Available online: http:/ / www.scielo.org.mx/pdf/era/v3n8/2007-901X-era-3-08-00243.pdf (accessed on 1 February 2021).

21. SENASICA. Available online: https://www.gob.mx/senasica/documentos/situacion-actual-del-control-de-la-garrapataboophilus-spp (accessed on 11 September 2021).

22. Jaramillo, O.J.M.; Montenegro, V.N.; de la Fournière, S.A.; Sarmiento, N.F.; Farber, M.D.; Wilkowsky, S.E. Development of an indirect ELISA based on a recombinant chimeric protein for the detection of antibodies against bovine babesiosis. Vet. Sci. 2018, 5, 13. [CrossRef]

23. Nguyen, T.T.; Zhou, M.; Ruttayaporn, N.; Nguyen, Q.D.; Nguyenb, V.K.; Goto, Y.; Suzuki, Y.; Kawazu, S.; Inoue, N. Diagnostic value of the recombinant tándem repeat antigen TeGM6-4r for surra in water buffaloes. Vet. Parasitol. 2014, 201, 18-23. [CrossRef]

24. Álvarez, J.A.; López, U.; Rojas, C.; Borgonio, V.M.; Sanchez, V.; Castañeda, R.; Vargas, P.; Figueroa, J.V. Immunization of Bos taurus steers with Babesia bovis recombinant antigens MSA-1, MSA-2c and 12D3. Transbound. Emerg. Dis. 2010, 57, 87-90. [CrossRef] [PubMed]

25. Santamaria, R.M.; Lira, J.J.; Vargas, P.; Alvarez, J.A.; Rojas, C.; Figueroa, J.V. Validation of an indirect ELISA using recombinant proteins as antigen to identify animals exposed to Babesia bigemina. Transbound. Emerg. Dis. 2020, 67, 1-7. [CrossRef] [PubMed]

26. Kim, C.M.; Alhassan, A.; Verdida, R.A.; Yokoyama, N.; Xuan, X.; Fujisaki, K.; Kawasu, S.; Igarashi, I. Development of two immunochromatographic tests for the serodiagnosis of bovine babesiosis. Vet. Parasitol. 2007, 148, 137-143. [CrossRef] [PubMed]

27. Huang, X.; Xuan, X.; Hirata, H.; Yokoyama, N.; Xu, L.; Susuki, N.; Igarashi, I. Rapid immunochromatographic test using recombinant SAG-2 for detection of antibodies against Toxoplasma gondii in cats. J. Clin. Microbiol. 2004, 42, 351-353. [CrossRef] [PubMed]

28. Terkawi, M.A.; Kameyama, K.; Rasul, N.H.; Xuan, X.; Nishikawa, Y. Development of an immunochromatographic assay based on dense granule protein 7 for serological detection of Toxoplasma gondii. Clin. Vaccine Immunol. 2013, 20, 596-601. [CrossRef]

29. Silva, F.A.C.; Molina, V.M. Likelihood ratio (razón de verosimilitud): Definición y aplicación en radiología. Rev. Argen. Radiol. 2017, 81, 204-208. [CrossRef] 
30. Reyes, S.R.M.; Bautista, G.C.R.; Castañeda, A.R.O.; Vargas, U.P.; Álvarez, M.J.A.; Rojas, M.C.; Mejía, E.F.; Figueroa, M.J.V. Babesiosis: Field assessment of protection in cattle immunized with a mixture of Babesia bovis recombinant proteins. Quehacer cient. Chiapas. 2016, 11, 36-46. Available online: https://www.dgip.unach.mx/images/pdf-REVISTA-QUEHACERCIENTIFICO/ 2016-jul-dic/Babesiosis_Field_assessment_of_protection_in_cattle.pdf (accessed on 1 February 2021).

31. Lira, A.J.J.; Polanco, M.D.J.; Castañeda, A.R.O.; Ramos, A.J.A.; Lara, H.E.J.; Preciado, T.J.F.; Rojas, M.C.; Álvarez, M.J.A.; Bautista, G.C.R.; Figueroa, M.J.V. Prevalencia serológica y molecular de Babesia bovis, Babesia bigemina y Anaplasma marginale en búfalos de agua mantenidos en zonas de alta incidencia de garrapatas. Entomol. Mex. 2017, 4, 627-632. Available online: https:/ / www.socmexent.org/entomologia/revista/2017/EV/EM1502017_627-632.pdf (accessed on 1 February 2021).

32. Bose, R.; Jorgensen, W.K.; Dalgliesh, R.J.; Friedhoff, K.T.; de Vos, A.J. Current state and future trends in the diagnosis of babesiosis. Vet. Parasitol. 1995, 57, 61-74. [CrossRef]

33. Richardson, D.C.; Ciach, M.; Zhong, K.J.Y.; Crandall, I.; Kain, K.C. Evaluation of the Makromed dipstick assay versus PCR for diagnosis of Plasmodium falciparum malaria in returned travelers. J. Clin. Microbiol. 2002, 40, 4528-4530. [CrossRef]

34. Smits, H.L.; Eapen, C.K.; Sugathan, S.; Kurikose, M.; Gasem, H.; Yersin, C.; Sasaki, D.; Punjianto, B.; Vestering, M.; Abdoel, T.; et al. Lateral-flow assay for rapid serodiagnosis of human leptospirosis. Clin. Diagn. Lab. Immunol. 2001, 8, 166-169. [CrossRef]

35. Rhemrev-Boom, M.M.; Yates, M.; Rudolph, M.; Raedts, M. (Immuno) affinity chromatography: A versatile tool for fast and selective purification, concentration, isolation and analysis. J. Pharm. Biomed. Anal. 2001, 24, 825-833. [CrossRef]

36. Figueroa-Millán, J.V.; Castañeda-Arriola, R.O.; Lira-Amaya, J.J.; Vargas-Urióstegui, P.; Álvarez-Martínez, J.A.; Rojas-Martínez, C. ELISA test using Babesia sp. recombinant antigens for epidemiological diagnosis of bovine babesiosis in Mexico. In ELISA: Advances in Research and Application; submitted; Angeles, J.M., Ed.; Nova Science Publishers: Hauppauge, NY, USA, 2021.

37. El-Sayed, S.; Rizk, M.A.; Terkawi, M.; Igarashi, I. Cocktail Babesia bovis antigens for global detection of Babesia bovis infection in cattle. Exp. Parasitol. 2019, 206, 107758. [CrossRef] [PubMed]

38. Huang, X.; Xuan, X.; Verdida, R.A.; Zhang, S.; Yokoyama, N.; Xu, L.; Igarashi, I. Immunochromatographic test for simultaneous serodiagnosis of Babesia caballi and Babesia equi infection in horses. Clin. Vaccine Immunol. 2006, 13, 553-555. [CrossRef] [PubMed]

39. Liao, M.; Zhang, S.; Xuan, X.; Zhang, G.; Huang, X.; Igarashi, I.; Fujusaki, K. Development of rapid immunochromatographic test with recombinant NcSAG1 for detection of antibodies to Neospora caninum in cattle. Clin. Vaccine Immunol. Clin. 2005, 12, 885-887. [CrossRef]

40. Lu, Y.; Guan, G.; Jiang, T.; Li, Y.; Yang, J.; Liu, G.; Luo, J.; Yin, H.; Liu, Z. Development of an immunochromatographic strip for the serodiagnosis of Theileria infection in sheep. Parasit. Vectors 2015, 8, 621. [CrossRef]

41. Borgonio, V.M.; Mosqueda, J.J.; Genis, A.D.; Falcón, A.; Álvarez, J.A.; Camacho, M.; Figueroa, J.V. msa-1 and msa-2c gene analysis and common epitopes assessment in Mexican B. bovis isolates. Ann. N. Y. Acad. Sci. 2008, 1149, 145-148. [CrossRef]

42. Hines, S.A.; Palmer, G.H.; Jasmer, D.P.; Goff, W.L.; Mcelwain, T.F. Immunization of cattle with recombinant Babesia bovis merozoite surface antigen-1. Infect. Immun. 1995, 63, 349-352. Available online: https://www.ncbi.nlm.nih.gov/pmc/articles/PMC172999/ (accessed on 1 February 2021). [CrossRef]

43. Hines, S.A.; Palmer, G.H.; Jasmer, D.P.; McGuire, T.C.; McElwain, T.F. Neutralization-sensitive merozoite surface antigens of Babesia bovis encoded by members of a polymorphic gene family. Mol. Biochem. Parasitol. 1992, 55, 85-94. [CrossRef]

44. Yokoyama, N.; Okamura, M.; Igarashi, I. Erythrocyte invasion by Babesia parasites: Current advances in the elucidation of the molecular interactions between the protozoan ligands and host receptors in the invasion stage. Vet. Parasitol. 2006, 138, 22-32. [CrossRef]

45. Kemp, L.E.; Yamamoto, Y.; Soldati, F.D. Subversion of host cellular functions by the apicomplexan parasites. Microbiol. Rev. 2013, 37, 607-631. [CrossRef] [PubMed] 